\title{
Metformin Pretreatment Ameliorates Diabetic Nephropathy Induced by a Combination of High Fat Diet and Streptozotocin in Rats
}

\author{
El Pretratamiento con Metformina Mejora la Nefropatía Diabética Inducida \\ por una Combinación de Dieta Alta en Grasas y Estreptozotocina en Ratas
}

\author{
Mohammad Dallak ${ }^{1}$; Ismaeel Bin-Jaliah¹; Fahaid Al-Hashem'; Samaa S. Kamar²; \\ Dina H. Abdel Kader'; Shaimaa N. Amin ${ }^{3}$; Mohamed A. Haidara ${ }^{1,3}$ \& Bahjat Al-Ani ${ }^{1}$
}

DALLAK, M.; BIN-JALIAH, I.; AL-HASHEM, F.; KAMAR, S. S.; KADER, D. H. A.; AMIN, S. N.; HAIDARA, M. A. \& ALANI, B. Metformin pretreatment ameliorates diabetic nephropathy induced by a combination of high fat diet and streptozotocin in rats. Int. J. Morphol., 36(3):969-974, 2018.

SUMMARY: Kidney injury secondary to diabetes is the most common cause of kidney failure. We sought to determine whether pretreatment with the insulin-sensitizing drug metformin prior to the induction of diabetes can protect the kidney against the development of diabetic nephropathy (DN) induced by a combination of a high-fat diet and streptozotocin. Rats were either injected with vehicle (control group) or with a single injection of streptozotocin (STZ) $(50 \mathrm{mg} / \mathrm{kg}$ ) two weeks after being fed on a high-fat diet (HFD) (model group) and continued on HFD until being sacrificed 10 weeks post diabetic induction. The protective group that also fed on a HFD for 12 weeks was put on metformin ( $200 \mathrm{mg} / \mathrm{kg}$ /day) two weeks before STZ injection and continued on metformin until the sacrifice day. Harvested kidney tissues were examined by light microscopy after staining with hematoxylin and eosin (H\&E) and periodic acid Schiff (PAS). Blood samples were assayed for sugar, urea, creatinine, and biomarkers of inflammation. Compared to a normal tissue histology in the control group, there was a profound damage to the kidney in the model group as demonstrated by markedly dilated capsular space, increased mesangial matrix expansion, congested blood vessels, and many tubular epithelial cells showing small pyknotic nuclei and vacuolated cytoplasm, which were significantly but not completely protected by metformin. Our findings also show that metformin significantly inhibited the inflammatory biomarkers, tumor necrosis factor-alpha (TNF- $\alpha$ ) and C-reactive protein (CRP) induced by diabetes and HFD as well as significantly inhibiting blood sugar, urea, and creatinine. However, the levels of TNF- $\alpha$, CRP, glucose, and creatinine in the metformin-treated group was still significant to the control group. Thus, we demonstrated an efficient but not complete protection by metformin pretreatment against DN induced by a combination of HFD and streptozotocin in rats.

KEY WORDS: Diabetic nephropathy; Metformin; Inflammation; Rat model.

\section{INTRODUCTION}

Excessive calorie consumption and reduced physical activity account for the observed rapid rise in obesity that claims an estimated 35 million obesity-related deaths worldwide per annum including diabetes and its complications (Lustig et al., 2012). Obesity is associated with the loss of insulin sensitivity (insulin resistance), which is widely recognized as a key component of the pre-diabetic state and a vital characteristic of the metabolic syndrome (Kopelman, 2000; Lustig et al.). Additionally, obesity is also associated with hypertension, and renal dysfunction contributes to diabetic nephropathy (DN), glomerulopathy and renal failure (Iseki et al., 2004; Shen et al., 2010; Bayliss et al., 2012). Hyperglycaemia stimulates the generation of inflammatory biomarkers and reactive oxygen species (ROS) such as superoxide through both mitochondria and NADPH oxidase and represents a common mechanism underlying the vascular injury observed in insulin resistance (Shoelson et al., 2006).

DN is characterized by a progressive increase in proteinuria and decline in glomerular filtration rate (GFR), hypertension, and a high risk ofcardiovascular morbidity and 
mortality (Russell, 2006; Lim, 2014). Patients that develop diabetes have a significantly higher risk of developing DN, and approximately $20-50 \%$ of diabetic patients progress to renal failure, and in the USA alone, nearly $44 \%$ of new cases of end-stage renal failure are caused by diabetes (Dalla Vestra et al., 2000). Kidney injury, inflammation and fibrosis of the glomeruli and the proximal tubular cells together with the activation of the renin-angiotensin system that increases the glomerular capillary pressure all contribute to the progression of DN (Jefferson et al., 2008; Chawla et al., 2010).

Targeting the problem of DN was proven to be effective in delaying the prognosis of the disease; for example, inhibiting the rennin-angiotensin system by angiotensin-converting enzyme inhibitors (ACEI), captopril in DN patients was reported to protect against deterioration in renal function and associated with $50 \%$ reduction in the risk of reaching the end-stage renal failure (Chawla et al.). The anti-hyperglycaemic and antioxidant drug, metformin was shown to ameliorate several types of kidney diseases such as renal podocyte injury and gentamicin-induced renal toxicity in rats (Amini et al., 2012), but did not hinder the rise in albumin/creatinine ratio (ACR) in patients with T2DM (Lachin et al., 2011). This study targeted the problem of $\mathrm{DN}$ by investigating the potential protective effects of metformin pretreatment before the induction of diabetes against the development of diabetic nephropathy (DN) induced by a combination of high-fat diet and streptozotocin in rats using histological and biochemical approaches.

\section{MATERIAL AND METHOD}

Animals. Albino male rats weighing 180- 200 gm were used for the experiments with the approval of Ethical Committee of the college of medicine, King Khalid University, Abha, Saudi Arabia. The animals were obtained from the animal house of the College of Medicine of King Khalid University where they fed with standard rat pellets and allowed free access to water. They were housed at a controlled ambient temperature of $25 \pm 2{ }^{\circ} \mathrm{C}$ and $50 \pm 10$ $\%$ relative humidity, with 12 -h light/12-h dark cycles. Experiments were performed according to the Guide for the Care and Use of Laboratory Animals published by the US National Institutes of Health (NIH publication No. 8523, revised 1996).

Experimental design. After a one week adaptation, rats were randomly divided into three groups ( $n=8$ rats each) as follows: Control group (Control): non-diabetic, non- treated rats that were injected intraperitoneally (i.p.) once with citrate buffer $(0.1 \mathrm{M}, \mathrm{pH} 4.5)$ and fed with standard laboratory chow for 12 weeks; Diabetic type 2 group ( T2DM ): rats were fed a high carbohydrate and fat diet (HCFD) (Collino et al., 2010) for two weeks and then DM was induced in rats by a single i.p. Injection of streptozotocin (STZ) in a dose of $50 \mathrm{mg} / \mathrm{kg}$. Then rats were continuously fed a HCFD until the end of the experiment, end of week 12; metformin and T2DM group (Met + T2DM): animals in the protective group were put on metformin (200 $\mathrm{mg} / \mathrm{kg}$ body weight) from day 1 and fed with HCFD for two weeks before inducing T2DM as in group 3. Then rats were carried receiving metformin and fed a HCFD until being sacrificed, on week 12. At the end of the experiment, rats were sacrificed, and blood and kidneys were collected.

Histopathological studies. Kidney specimens were obtained, sectioned and immediately fixed in $10 \%$ formol saline for $24 \mathrm{~h}$. Paraffin blocks were prepared and $5 \mathrm{~mm}$ thick sections were subjected to hematoxylin and eosin (H\&E) and Periodic acid Schiff (PAS) reaction with hematoxylin as a counterstain. Morphometry and statistical analysis of the mean width of Bowman's space in H\&Estained sections were measured in 10 non overlapping fields for each group using "Leica Qwin 500 C" image analyzer (Cambridge, UK). Quantitative data were summarized as means and standard deviations (SD) and compared using analysis of variance (ANOVA) followed by post-Hoc analysis (Tukey test). P-value $<0.05$ was considered statistically significant. Calculations were made on SPSS software (version 19).

Blood sugar and urea and creatinine. Serum glucose was determined colorimetrically using a Randox reagent kit (Sigma-Aldrich). Serum urea and creatinine were measured using colorimetric methods according to manufacturer's instruction (BioAssay System, USA).

\section{Blood measurement of TNF- $\alpha$ and hs-CRP inflammatory biomarkers. TNF- $\alpha$, (ELISA kit BIOTANF INC, Cat. No. R6365) was used as recommended by the manufacturer. ELISA kits were purchase to determine serum levels of high sensitive C-reactive protein (hs-CRP, Cat. No. ERC1021-1) from ASSAYPRO, USA.}

Statistical analysis. The data were expressed as the mean \pm standard deviation (SD). Data were processed and analyzed using the SPSS version 10.0 (SPSS, Inc., Chicago, Ill., USA). One-way ANOVA was done followed by Tukey's post hoc test. Pearson correlation statistical analysis was done for detection of a probable significance between two different parameters. Results were considered significant if $\mathrm{p} \leq 0.05$. 


\section{RESULTS}

Induction of diabetic nephropathy secondary to diabetes and HFD. Seven out of eight rats $(87.5 \%)$ in the model group developed diabetes $(\geq 210 \mathrm{mg} / \mathrm{dL})$ that was confirmed one week after injecting these rats with a single dose of STZ $(50 \mathrm{mg} / \mathrm{kg})$. High blood levels of urea and creatinine (Figs. $1 \mathrm{~A}$ and 1B), and kidney histology (Figs. 1C and 1D) confirmed DN in the model group. H\&E stained images of glomeruli from the model group showed markedly dilated capsular space and glomerular capillaries, and the tubular epithelial lining displayed many cells with pyknotic nuclei and others with vacuolated cytoplasm (Fig. 1D). By comparison control group (Fig. 1C) showed normal renal corpuscles and tubules and narrow Bowman's space. Also, PAS-stained renal cortex sections prepared from the model group revealed increased mesangial matrix expansion, which further confirms DN development secondary to diabetes and HFD (data not shown).

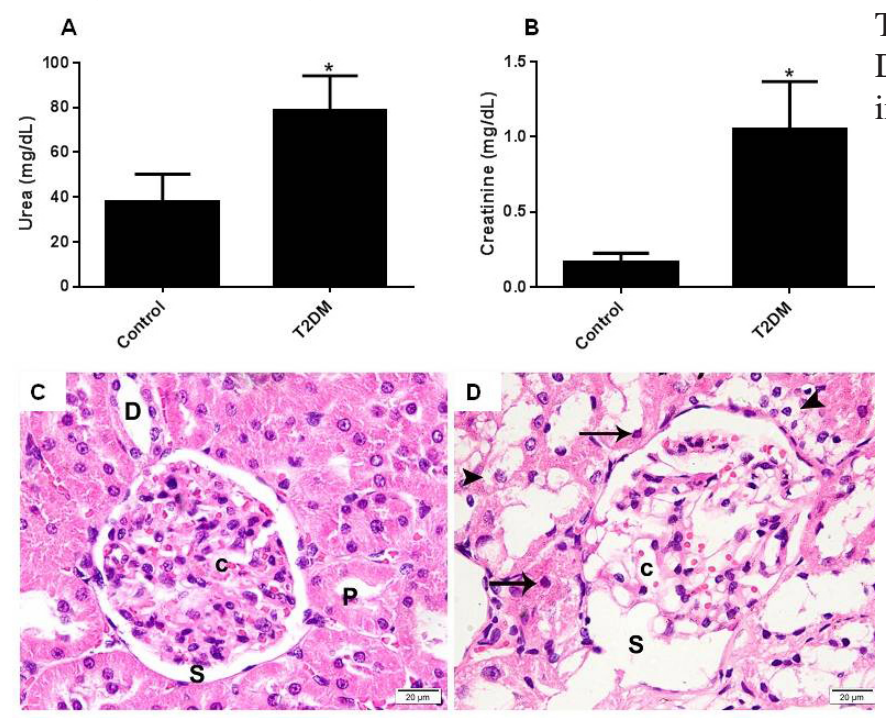

Metformin protects against a rise in kidney injury biomarkers induced by diabetes and HFD. High blood urea and creatinine are well-known kidney injury biomarkers in diabetic humans and animal models of diabetes. To test the hypothesis that metformin pretreatment can suppress kidney injury biomarkers in diabetic rats placed on a HFD, we measured these parameters in the three animal groups involved in this study. Diabetic rats fed on a HFD for 12 weeks showed a marked increase in blood urea and creatinine which were protected by metformin (Figs. 2A and 2B). Metformin also protected against a sharp increase in blood glucose (Fig. 2C). The inhibition was incomparable to controls for blood creatinine and glucose. The relative degree of protection by metformin was creatinine $>$ urea $\leq$ glucose.

Metformin protects against a rise in inflammatory biomarkers induced by diabetes and HFD. To investigate whether metformin pretreatment can protect against a rise in inflammatory biomarkers induced by HFD and the diabetes-inducing agent, STZ, we measured the blood level of TNF- $\alpha$ and hs-CRP 10 weeks after induction of diabetes. Diabetic rats fed on a HFD for 12 weeks showed a marked increase in blood TNF- $\alpha$ and hs-CRP which were protected

Fig. 1. Induction of DN in rats by HFD and STZ. Blood levels of urea (A) and creatinine (B) were measured ten weeks postSTZ injections in the model group compared to the control group. Results represent the mean $( \pm \mathrm{SD})$, and experiments were performed in triplicate. $* \mathrm{p}<0.05$ versus control. (C and D). H\&E stained images (x400) of harvested tissues obtained from the kidney of model group (C) compared to the control group (B) rats are visualized using light microscopy. Note that arrows and arrowheads point to pyknotic nuclei and vacuolated cytoplasm, respectively. Abbreviations: C, renal corpuscles; $\mathrm{D}$, distal convoluted tubules; $\mathrm{P}$, proximal convoluted tubules; S, Bowman's space.
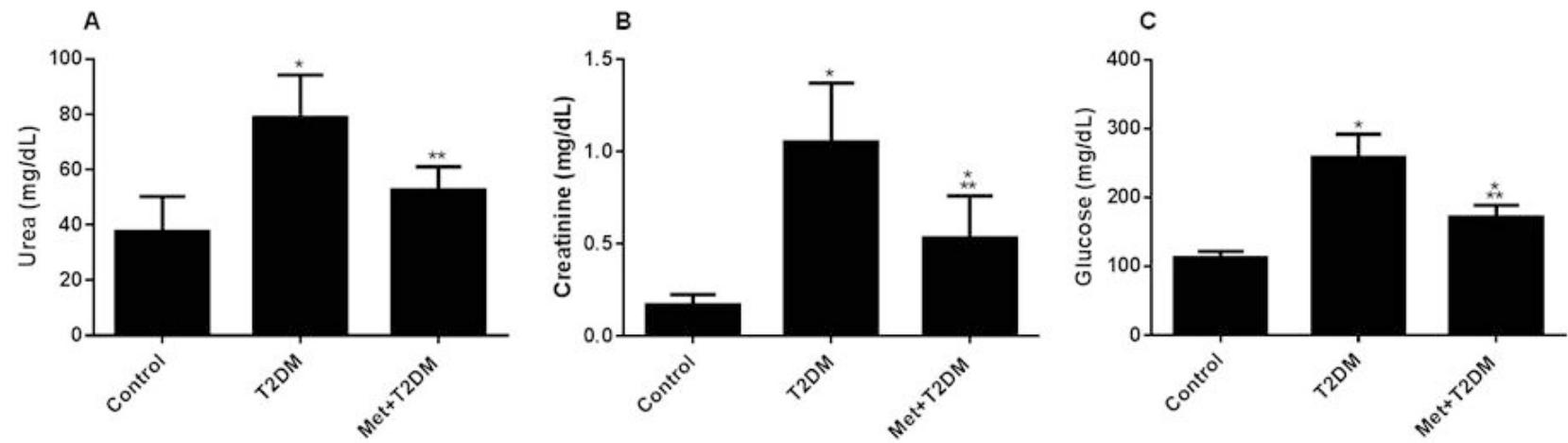

Fig. 2. Metformin inhibits HFD and diabetes that caused induction of kidney injury biomarkers. Blood levels of urea (A), creatinine (B), and glucose $(\mathrm{C})$ were measured 12 weeks after the start of metformin pretreatment protocol and 10 weeks post STZ injections in rats. Results represent the mean $( \pm \mathrm{SD}) ; \mathrm{n}=8$ for each group. Experiments were performed in triplicate. All shown $\mathrm{p}$ values are significant. $* \mathrm{p}<0.05$ versus control, $* * \mathrm{p}<0.05$ versus $\mathrm{T} 2 \mathrm{DM}$. 
by metformin (Fig. 3A and 3B). However, the level of TNF$\alpha$ and hs-CRP in the Met+T2DM group was still significant to control. The relative degree of protection by metformin was TNF- $\alpha>$ hs-CRP $>$ glucose.

Metformin protects kidney tissue against DN damage induced by diabetes and HFD. To test the hypothesis that metformin can protect kidney organ against injuries induced by diabetes and HFD, we pretreated a group of rats (Met + T2DM) with metformin $(200 \mathrm{mg} / \mathrm{kg}$ ) daily starting two weeks before the induction of diabetes by STZ and continued until animals were sacrificed, end of week 12. Kidney tissues were prepared from all the groups and visualized using light microscopy. The control group showed intact kidney architecture (Figs. 4A and 4B). Diabetic rats showed (Figs. 4C and 4D) a markedly dilated capsular space (S), congested blood vessels $(\mathrm{V})$ and dilated tubules. The tubular epithelial lining is displaying many cells with small pyknotic nuclei (arrows) others showing markedly vacuolated cytoplasm, thinning of the cell membrane and bulging of the affected cells into the lumen (arrowheads). Metformin substantially preserved kidney tissues (Figs. 4E and 4F) from the deleterious effects of diabetes and HFD as shown by mild dilatation of glomerular capillaries and capsular space (S). Few tubular cells have pyknotic nuclei (arrows). Quantitative analysis of the mean diameter of Bowman's space revealed substantial protection by metformin but again was incomparable to the control group (Fig. 4G).
A

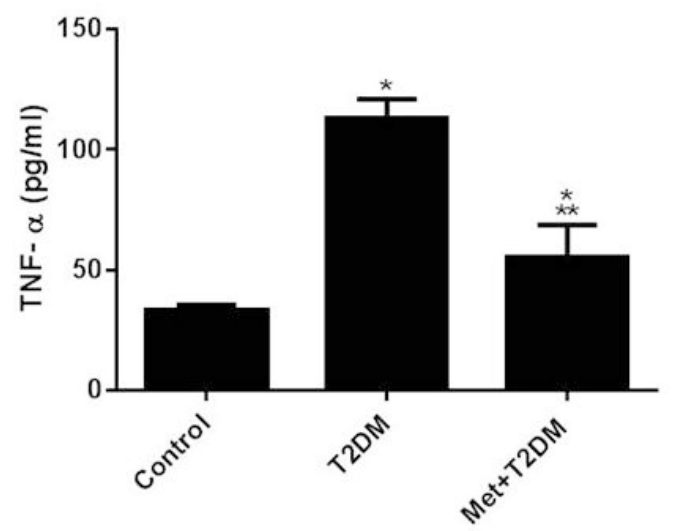

B

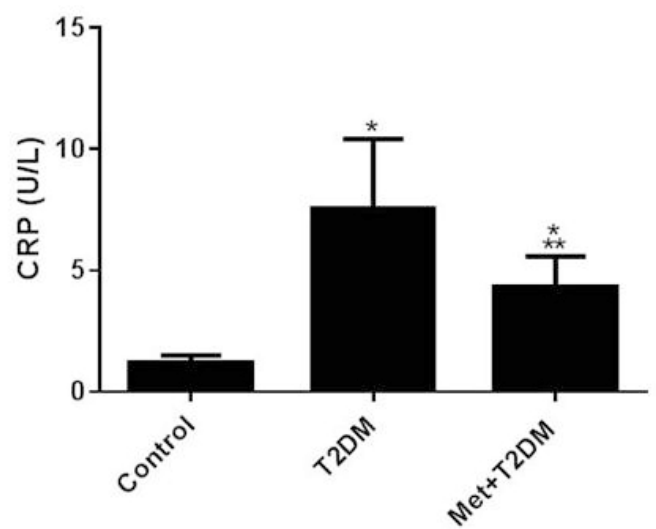

Fig. 3. Metformin inhibits HFD and diabetes that caused induction of inflammatory biomarkers. Blood levels of TNF-? (A) and hs-CRP (B), were measured 12 weeks after the start of metformin pretreatment protocol and 10 weeks post-STZ injections in rats. Results represent the mean $( \pm S D) ; n=8$ for each group. Experiments were performed in triplicate. All shown $\mathrm{p}$ values are significant. ${ }^{*} \mathrm{p}<0.05$ versus control, $* * \mathrm{p}<0.05 \mathrm{versus}$ T2DM.

\section{DISCUSSION}

The present study demonstrates that the protection against the development of DN secondary to diabetes and HFD using the anti-hyperglycaemic and antioxidant drug, metformin before STZ injection can slow down the progression of the disease in rats. This conclusion is supported by the data indicating that metformin substantially but not completely prevented kidney injuries occurred after 10 weeks in diabetic rats fed on a HFD (Figs. 1 and 4). Furthermore, metformin significantly inhibited the elevation of blood urea, creatinine, sugar, and inflammatory biomarkers (Figs. 2 and 3) that are known to be elevated in DN (Korczowska \& Lacki, 2005). However, none of the measured biochemical parameters, except blood urea, have returned to control levels in the protective group (Figs. 2 and 3). These observations may explain in part why we have not yet achieved complete protection against DN with metformin (Fig. 4G).

Treating DN in rats with metformin was recently reported (Zhang et al., 2017). Their approach was different from ours as they started the treatment after injecting STZ and rats were fed on a HFD for eight weeks prior to diabetic induction, yet their results that demonstrate partial protection to $\mathrm{DN}$ are in agreement with our findings. A second report also demonstrated partial protection of the glomerular podocyte in rats by metformin post-STZ injection using electron microscopy technique (Zhai et al., 2015). Furthermore, meta-analysis study of metformin in diabetic 


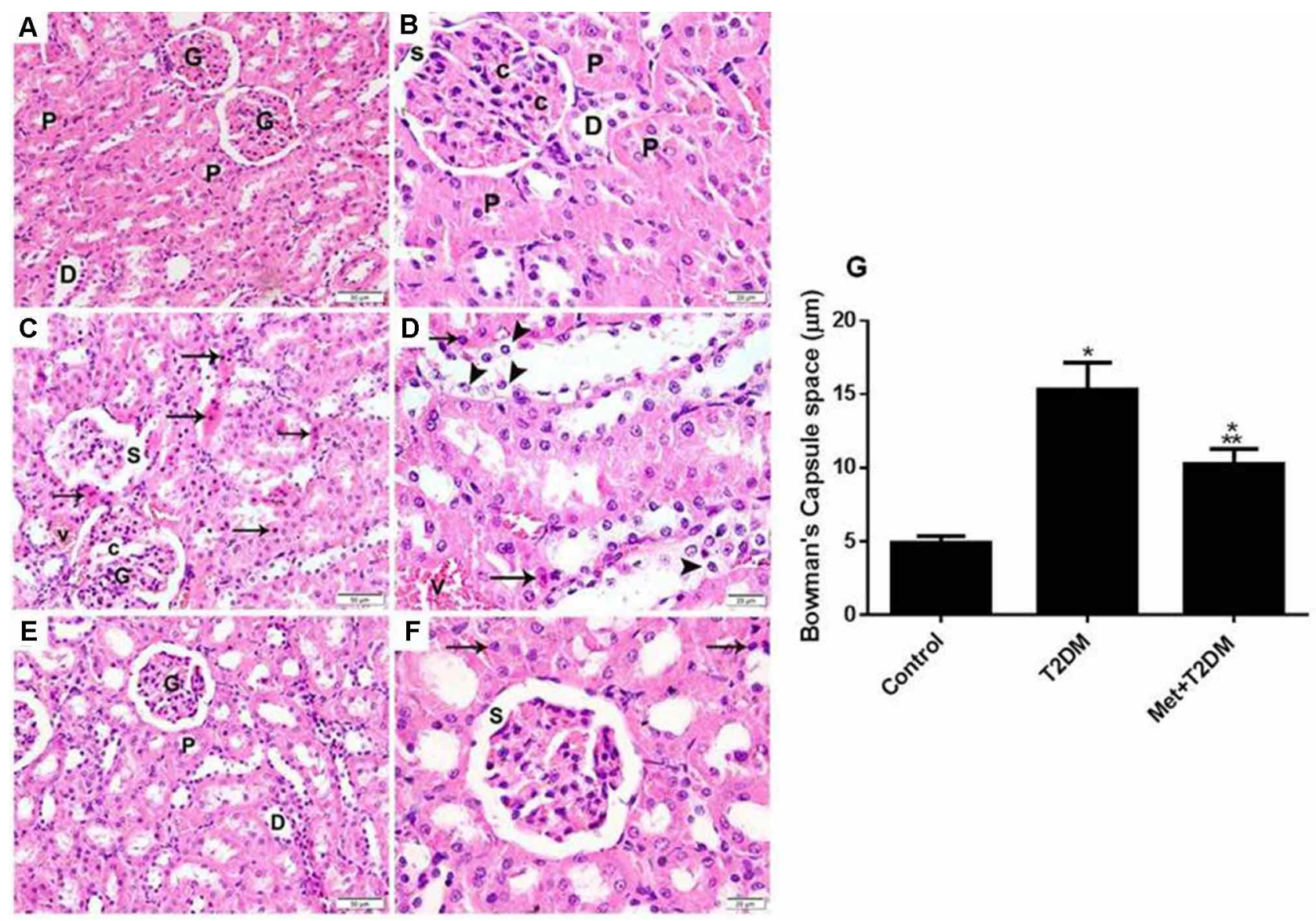

Fig. 4. Metformin protects against HFD and diabetes-induced DN. H\&E stained images (x200) of harvested tissues obtained after 12 weeks from the kidney in different groups of rats used in the study; Control group (A and B), model group (C and D), and Met+T2DM, protective group (E and F). Quantitative analysis of the mean diameter of Bowman's space is shown in (G). Note that arrows are shown in $\mathrm{C}, \mathrm{D}$, and F point to pyknotic nuclei; and arrowheads in $\mathrm{D}$ point to the thinning of the cell membrane and bulging of the affected cells into the lumen. Abbreviations: G, renal corpuscles; D, distal convoluted tubules; P, proximal convoluted tubules; C, glomerular capillaries; S, Bowman's space; V, congested blood vessels.

patients treated for 5 years before developing DN (Lachin et al.) showed that metformin was partially protected against $\mathrm{DN}$, which is in agreement with our study and others. Therefore, our data that point to the partial protection of DN with metformin together with these reports may support the need for a better protecting agent(s).

Collectively, our biochemical and histological data support the conclusion that feeding rats on a HFD for 12 weeks with a single injection of STZ led to the development of DN, which was partially protected by metformin.

ACKNOWLEDGMENT. The author would like to thank Dr. Mariam Al-Ani from Dental Care Partnership, Sutton Coldfield, Birmingham, UK for proofreading the manuscript.
DALLAK, M.; BIN-JALIAH, I.; AL-HASHEM, F.; KAMAR, S. S.; KADER, D. H. A.; AMIN, S. N.; HAIDARA, M. A. \& AL-ANI, B. El pretratamiento con metformina mejora la nefropatía diabética inducida por una combinación de dieta alta en grasas y estreptozotocina en ratas. Int. J. Morphol., 36(3):969-974, 2018.

RESUMEN: La lesión renal secundaria a la diabetes es la causa más común de insuficiencia renal. Intentamos determinar si el pre tratamiento con metformina, un fármaco sensibilizante a la insulina antes de la inducción de diabetes, puede proteger al riñón del desarrollo de la nefropatía diabética (DN) inducida por una combinación de una dieta alta en grasas y estreptozotocina. Las ratas fueron inyectadas con el medio (grupo de control) o con una inyección única de estreptozotocina (STZ) $(50 \mathrm{mg} / \mathrm{kg}$ ) dos semanas después de ser alimentadas con una dieta alta en grasas (HFD) (grupo modelo) y continuaron en HFD hasta ser sacrificadas 10 semanas después de la inducción diabética. El grupo protector que también se alimentó con un HFD durante 12 semanas recibió metformina (200 mg / kg / día) dos semanas antes de la inyección 
de STZ y continuó con metformina hasta el día en que fueron sacrificadas. Las muestras de riñón se examinaron mediante microscopía óptica después de la tinción con Hematoxilina y Eosina y ácido peryódico de Schiff (PAS). Las muestras de sangre se analizaron para determinar niveles de azúcar, urea, creatinina y biomarcadores de inflamación. Comparado con una histología tisular normal en el grupo control, hubo un daño profundo al riñón en el grupo modelo como lo demuestra el espacio capsular marcadamente dilatado, el aumento de la expansión de la matriz mesangial, los vasos sanguíneos congestionados y muchas células epiteliales tubulares que muestran pequeños núcleos picnóticos y citoplasma vacuolado, que fueron significativamente pero no completamente protegidos por la metformina. Nuestros hallazgos también muestran que la metformina inhibe significativamente los biomarcadores inflamatorios, el factor de necrosis tumoral alfa (TNF-a) y la proteína $\mathrm{C}$ reactiva (PCR) inducida por diabetes y DFH, e inhibe significativamente el azúcar en sangre, la urea y la creatinina. Sin embargo, los niveles de TNF-a, CRP, glucosa y creatinina en el grupo tratado con metformina todavía eran significativos para el grupo de control. Por lo tanto, demostramos una protección eficiente pero no completa mediante pretratamiento con metformina contra DN inducida por una combinación de HFD y estreptozotocina en ratas.

PALABRAS CLAVE: Nefropatía diabética; Metformina; Inflamación; Modelo de rata.

\section{REFERENCES}

Amini, F. G.; Rafieian-Kopaei, M.; Nematbakhsh, M.; Baradaran, A. \& Nasri, H. Ameliorative effects of metformin on renal histologic and biochemical alterations of gentamicin-induced renal toxicity in Wistar rats. J. Res. Med. Sci., 17(7):621-5, 2012.

Bayliss, G.; Weinrauch, L. A. \& D'Elia, J. A. Pathophysiology of obesityrelated renal dysfunction contributes to diabetic nephropathy. Curr. Diab. Rep., 12(4):440-6, 2012.

Chawla, T.; Sharma, D. \& Singh, A. Role of the renin angiotensin system in diabetic nephropathy. World J. Diabetes, 1(5):141-5, 2010.

Collino, M.; Aragno, M.; Castiglia, S.; Miglio, G.; Tomasinelli, C.; Boccuzzi, G.; Thiemermann, C. \& Fantozzi, R. Pioglitazone improves lipid and insulin levels in overweight rats on a high cholesterol and fructose diet by decreasing hepatic inflammation. Br. J. Pharmacol., 160(8):1892902, 2010.

Dalla Vestra, M.; Saller, A.; Bortoloso, E.; Mauer, M. \& Fioretto, P. Structural involvement in type 1 and type 2 diabetic nephropathy. Diabetes Metab., 26 Suppl. 4:8-14, 2000.

Iseki, K.; Ikemiya, Y.; Kinjo, K.; Inoue, T.; Iseki, C. \& Takishita, S. Body mass index and the risk of development of end-stage renal disease in a screened cohort. Kidney Int., 65(5):1870-6, 2004.

Jefferson, J. A.; Shankland, S. J. \& Pichler, R. H. Proteinuria in diabetic kidney disease: a mechanistic viewpoint. Kidney Int., 74(1):22-36, 2008.

Kopelman, P. G. Obesity as a medical problem. Nature, 404(6778):63543, 2000.

Korczowska, I. \& Lacki, J. K. Changes in certain biochemical markers of bone turnover in rheumatoid arthritis patients treated with short-term low dose glucocorticosteroids. Przegl. Lek., 62(12):1384-6, 2005.

Lachin, J. M.; Viberti, G.; Zinman, B.; Haffner, S. M.; Aftring, R. P.; Paul, G.; Kravitz, B. G.; Herman, W. H.; Holman, R. R.; Kahn, S. E. \& ADOPT Study Group. Renal function in type 2 diabetes with rosiglitazone, metformin, and glyburide monotherapy. Clin. J. Am. Soc. Nephrol., 6():1032-40, 2011.

Lim, A. K. H. Diabetic nephropathy - complications and treatment. Int. J. Nephrol. Renovasc. Dis., 7:361-81, 2014.

Lustig, R. H.; Schmidt, L. A. \& Brindis, C. D. Public health: The toxic truth about sugar. Nature, 482(7383):27-9, 2012.

Russell, T. A. Diabetic nephropathy in patients with type 1 diabetes mellitus. Nephrol. Nurs. J., 33(1):15-28, 2006.

Shen, W. W.; Chen, H. M.; Chen, H.; Xu, F.; Li, L. S. \& Liu, Z. H. Obesityrelated glomerulopathy: body mass index and proteinuria. Clin. J. Am. Soc. Nephrol., 5(8):1401-9, 2010.

Shoelson, S. E.; Lee, J. \& Goldfine, A. B. Inflammation and insulin resistance. J. Clin. Invest., 116(7):1793-801, 2006.

Zhai, L.; Gu, J.; Yang, D.; Wang, W. \& Ye, S. Metformin ameliorates podocyte damage by restoring renal tissue podocalyxin expression in type 2 diabetic rats. J. Diabetes Res., 2015:231825, 2015.

Zhang, S.; Xu, H.; Yu, X.; Wu, Y. \& Sui, D. Metformin ameliorates diabetic nephropathy in a rat model of low-dose streptozotocin-induced diabetes. Exp. Ther. Med., 14(1):383-90, 2017.

\section{Corresponding author: \\ Professor Bahjat Al-Ani \\ Department of Physiology \\ College of Medicine \\ King Khalid University \\ Abha 61421 \\ SAUDI ARABIA}

E-mail: bahjat_alani@yahoo.com

Received: 14-01-2018

Accepted: 12-03-2018 